\title{
Carbon geochemistry of plankton-dominated samples in the Laptev and East Siberian shelves: contrasts in suspended particle composition
}

\author{
Tommaso Tesi ${ }^{1,2,3}$, Marc C. Geibel ${ }^{1,2}$, Christof Pearce ${ }^{2,4,5}$, Elena Panova ${ }^{6}$, Jorien E. Vonk ${ }^{7}$, Emma Karlsson $^{1,2}$,

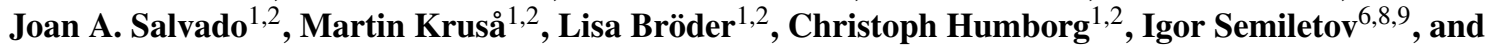 \\ Örjan Gustafsson ${ }^{1,2}$ \\ ${ }^{1}$ Department of Environmental Science and Analytical Chemistry (ACES), Stockholm University, Stockholm, Sweden \\ ${ }^{2}$ Bolin Centre for Climate Research, Stockholm University, Stockholm, Sweden \\ ${ }^{3}$ Institute of Marine Sciences, National Research Council (ISMAR-CNR), Bologna, Italy \\ ${ }^{4}$ Department of Geological Sciences, Stockholm University, Stockholm, Sweden \\ ${ }^{5}$ Department of Geoscience, Aarhus University, Aarhus, Denmark \\ ${ }^{6}$ Tomsk Polytechnic University, Tomsk, Russia \\ ${ }^{7}$ Vrije Universiteit Amsterdam (VU), Amsterdam, the Netherlands \\ ${ }^{8}$ Pacific Oceanological Institute FEB RAS, Vladivostok, Russia \\ ${ }^{9}$ University of Alaska Fairbanks, Fairbanks, USA
}

Correspondence to: Tommaso Tesi (tommaso.tesi@bo.ismar.cnr.it)

Received: 31 March 2017 - Discussion started: 10 April 2017

Revised: 9 August 2017 - Accepted: 12 August 2017 - Published: 18 September 2017

\begin{abstract}
Recent Arctic studies suggest that sea ice decline and permafrost thawing will affect phytoplankton dynamics and stimulate heterotrophic communities. However, in what way the plankton composition will change as the warming proceeds remains elusive. Here we investigate the chemical signature of the plankton-dominated fraction of particulate organic matter (POM) collected along the Siberian Shelf. POM $(>10 \mu \mathrm{m})$ samples were analysed using molecular biomarkers $\left(\mathrm{CuO}\right.$ oxidation and $\left.\mathrm{IP}_{25}\right)$ and dual-carbon isotopes $\left(\delta^{13} \mathrm{C}\right.$ and $\left.\Delta^{14} \mathrm{C}\right)$. In addition, surface water chemical properties were integrated with the POM $(>10 \mu \mathrm{m})$ dataset to understand the link between plankton composition and environmental conditions.

$\delta^{13} \mathrm{C}$ and $\Delta^{14} \mathrm{C}$ exhibited a large variability in the POM $(>10 \mu \mathrm{m})$ distribution while the content of terrestrial biomarkers in the POM was negligible. In the Laptev Sea (LS), $\delta^{13} \mathrm{C}$ and $\Delta^{14} \mathrm{C}$ of POM $(>10 \mu \mathrm{m})$ suggested a heterotrophic environment in which dissolved organic carbon (DOC) from the Lena River was the primary source of metabolisable carbon. Within the Lena plume, terrestrial DOC probably became part of the food web via bacteria
\end{abstract}

uptake and subsequently transferred to relatively other heterotrophic communities (e.g. dinoflagellates). Moving eastwards toward the sea-ice-dominated East Siberian Sea (ESS), the system became progressively more autotrophic. Comparison between $\delta^{13} \mathrm{C}$ of POM $(>10 \mu \mathrm{m})$ samples and $\mathrm{CO}_{2} \mathrm{aq}$ concentrations revealed that the carbon isotope fractionation increased moving towards the easternmost and most productive stations.

In a warming scenario characterised by enhanced terrestrial DOC release (thawing permafrost) and progressive sea ice decline, heterotrophic conditions might persist in the LS while the nutrient-rich Pacific inflow will likely stimulate greater primary productivity in the ESS. The contrasting trophic conditions will result in a sharp gradient in $\delta^{13} \mathrm{C}$ between the LS and ESS, similar to what is documented in our semi-synoptic study. 


\section{Introduction}

The progressive reduction of sea ice extent in the Arctic Ocean is indisputable evidence of modern global warming (Comiso et al., 2008; Ding et al., 2017; Kwok and Rothrock, 2009). The unprecedented decline of sea ice is expected to alter several aspects of the Arctic marine ecology such as plankton abundance and its temporal distribution (Arrigo et al., 2008). For instance, recent studies suggest that the increase of solar irradiance will stimulate greater primary productivity in summer while the prolonged ice-free conditions will develop a second algal bloom in early fall, which is a distinctive feature of only lower latitudes (Ardyna et al., 2014; Lalande et al., 2009, 2014). The phytoplankton communities are expected to profoundly change towards a higher contribution from open-water phytoplankton at the expense of sea ice assemblages (Fujiwara et al., 2014). Taken together, a greater productivity in the ice-free or marginal ice zone compared to the multi-year ice system is also expected to lead to greater carbon uptake and settling export of organic carbon from the surface to deeper strata of the Arctic Ocean (Gustafsson and Andersson, 2012).

Sea ice decline will also affect the water-air gas exchange, currents and river plume dispersion which, in turn, exert large control on the surface water chemical/physical properties (Aagaard and Carmack, 1989; Ardyna et al., 2014; Lalande et al., 2014). On top of this, destabilisation of permafrost soils and the terrestrial cryosphere will result in enhanced particulate and dissolved carbon input to the Arctic Ocean (Frey and Smith, 2005; Vonk et al., 2012). As a result, the geochemical signature of both autotrophic and heterotrophic plankton communities is also expected to change as the warming proceeds. However, how the warming will ultimately affect the marine geochemical signal is poorly understood. This study seeks a better understanding of the chemical composition of plankton that dominates regions of the Arctic Ocean characterised by different sea ice coverages, nutrient availability and riverine influence. In particular, we focus on the carbon isotope fingerprint (i.e. $\delta^{13} \mathrm{C}$ and $\Delta^{14} \mathrm{C}$ ) of plankton that grows in ice-covered and ice-free marginal ice zone (MIZ) regimes on the Siberian margin. The motivation behind investigating the chemical fingerprint of plankton from different regimes is to provide a better understanding of the carbon signature for direct applications to carbon studies of both modern systems and palaeo-reconstructions. In particular, the isotope composition of marine OC finds several applications in climate, ecology and carbon source apportionment studies. For example, stable carbon isotopes of marine phytoplankton are used for palaeo- $p \mathrm{CO}_{2}$ reconstructions over geological timescales (Hoins et al., 2015; Pagani et al., 1999; Popp et al., 1999; Rau, 1994). The $\delta^{13} \mathrm{C}$ signature also provides a solid tool for marine food web and ecosystem structure investigations (Dunton et al., 2006; Iken et al., 2005; Kohlbach et al., 2016). Furthermore, dual-carbon isotope mixing models $\left(\delta^{13} \mathrm{C}\right.$ and $\left.\Delta^{14} \mathrm{C}\right)$ are commonly used to quantify the relative proportion of marine and various allochthonous sources (e.g. permafrost soil) in both contemporary and palaeo-reconstructed carbon cycling of the Arctic (Karlsson et al., 2016; Tesi et al., 2016; Vonk et al., 2012, 2014).

With this overarching goal in mind, here we investigate the $>10 \mu \mathrm{m}$ fraction of particulate organic matter (POM) in ice-covered and ice-free MIZ regimes of the Siberian Arctic Shelf during the SWERUS-C3 expedition (July-August 2014) (Fig. 1). The plankton-dominated POM samples collected throughout the ca. $4500 \mathrm{~km}$ long cruise track were characterised using bulk parameters $\left(\mathrm{OC}, \delta^{13} \mathrm{C}\right.$ and $\Delta^{14} \mathrm{C}$ ) and biomarkers (highly branched isoprenoids, $\mathrm{IP}_{25} ; \mathrm{CuO}$ oxidation products). In addition, continuous measurements of dissolved $\mathrm{CO}_{2}\left(\mathrm{CO}_{2 \mathrm{aq}}\right)$ and its stable carbon isotope composition $\left(\delta^{13} \mathrm{C}_{\mathrm{CO}_{2}}\right)$ were performed during the campaign (Humborg et al., 2017) and used for a direct comparison with the chemical composition of the POM fraction.

\section{Study region}

The Laptev Sea and the East Siberian Sea are shallow epicontinental seas in the Russian Arctic separated by the New Siberian Islands (Fig. 1). Sea ice cover lasts for most part of the year over the shelf. Late spring/summer is characterised by the seasonal sea ice retreat coupled with river freshet which supplies large amount of terrestrial carbon in the form of particulate and dissolved matters (Karlsson et al., 2016; Salvadó et al., 2016; Sánchez-García et al., 2011). The Lena $\left(523 \mathrm{~km}^{3} \mathrm{yr}^{-1}\right)$, Indigirka $\left(54 \mathrm{~km}^{3} \mathrm{yr}^{-1}\right)$, and Kolyma $\left(48 \mathrm{~km}^{3} \mathrm{yr}^{-1}\right)$ are the major rivers (Gordeev, 2006). During the ice-free season, the Lena plume can be traced in the outer shelf of the Laptev Sea (Fichot et al., 2013; Salvadó et al., 2016; Sánchez-García et al., 2011) while Pacific inflow from the Bering strait affects further east the East Siberia margin (Semiletov et al., 2005). The Pacific inflow exerts control on the nutrient balance as it supplies phosphorous and silicate to an otherwise nutrient-depleted region (Anderson et al., 2011; Semiletov et al., 2005). Another important source of particulate material to the continental margin is the Pleistocene ice complex deposit (ICD) entering the ocean via coastal erosion (Lantuit et al., 2011; Vonk et al., 2012) which is the dominant carbon source between the Kolyma River and the Lena River (Vonk et al., 2012).

\section{Methods}

\subsection{POM $(<10 \mu \mathrm{m})$ sampling}

Seawater was pumped from a stainless steel inlet on the hull of the icebreaker Oden positioned at $8 \mathrm{~m}$ below the sea surface. The inlet system is tested and further described in Sobek and Gustafsson (2004) and Gustafsson et al. (2005). Figure 1a and $\mathrm{b}$ show the regions covered to harvest each 

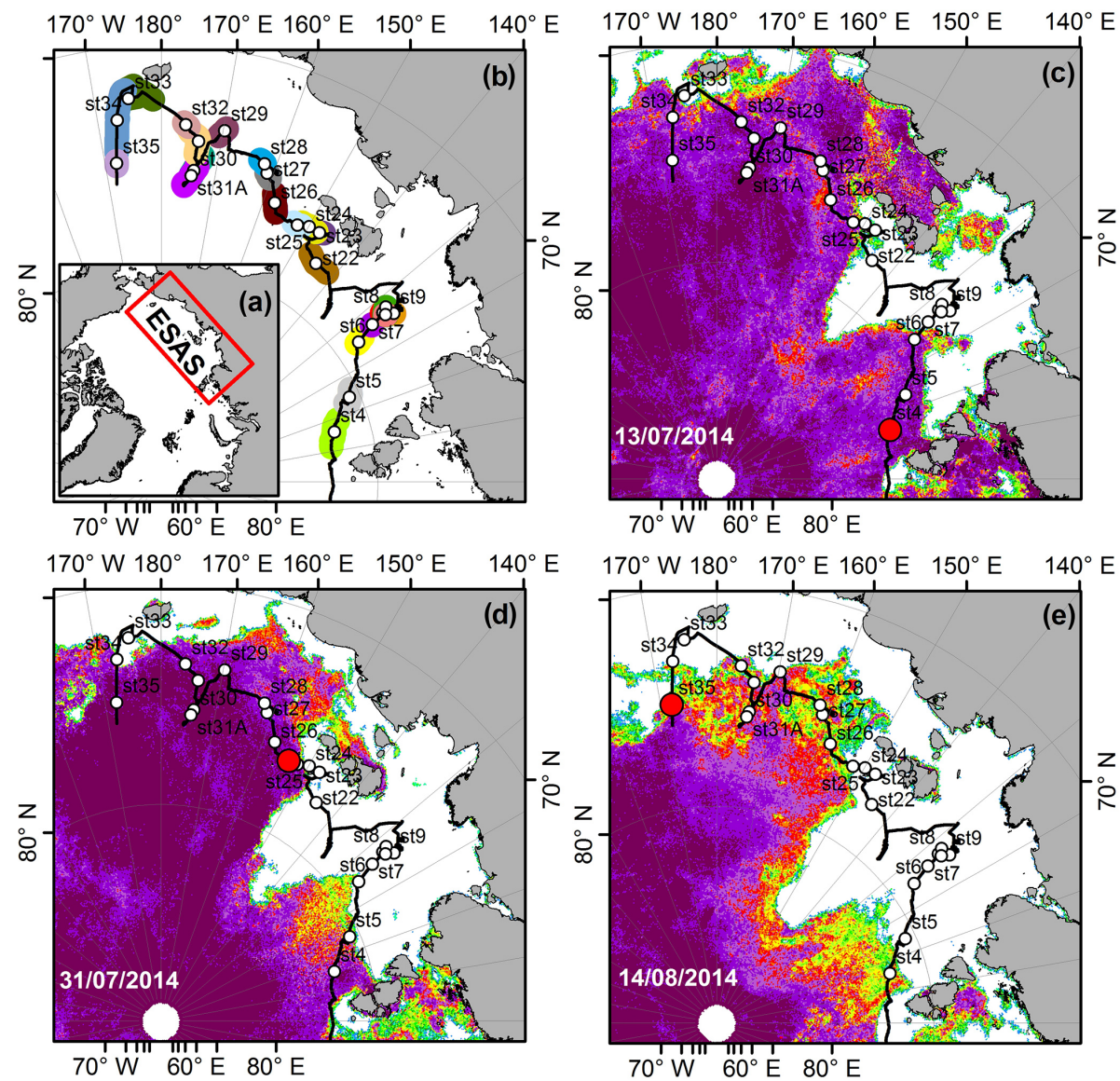

Sea ice coverage (\%)

\begin{tabular}{|c|c|c|c|}
\hline $0-9 \%$ & $30-39 \%$ & $60-69 \%$ & $85-89 \%$ \\
\hline $10-19 \%$ & $40-49 \%$ & $70-79 \%$ & $90-95 \%$ \\
\hline $20-29 \%$ & $50-59 \%$ & $80-84 \%$ & $96-98 \%$ \\
\hline
\end{tabular}

I/B Oden position

Figure 1. (a) The study area in the East Siberian Arctic Shelf. (b) Time-averaged position during the large-volume filtration (circles) of the POM $(>10 \mu \mathrm{m})$ samples. Shaded coloured areas show the sampling area covered to harvest each POM (>10 $\mu$ m) sample. Sea ice extent and concentration at the beginning (c), in the middle (d) and at the end (e) of the sampling campaign. The ship position is shown by a filled red circle.

POM $(>10 \mu \mathrm{m})$ sample with their location shown as timeaveraged position. The particulate material was retained via a large-volume filtration apparatus using a $10 \mu \mathrm{m} \mathrm{Nitex}{ }^{\circledR}$ (nylon) mesh placed in a $29.3 \mathrm{~cm}$ filter holder. After collection, filtered particulate material was transferred in pre-cleaned HDPE tubes by rinsing the Nitex ${ }^{\circledR}$ filters with Milli-Q water. Samples were kept frozen throughout the expedition. In the lab, samples were transferred in pre-cleaned Falcon ${ }^{\circledR}$ tubes (rinsed with $0.1 \mathrm{M} \mathrm{HCl}$ ) and gently centrifuged to remove the supernatant. The residual particulate material was frozen and subsequently freeze dried prior to biogeochemical analyses.

\subsection{Bulk carbon isotopes and biomarker analyses}

Organic carbon $(\mathrm{OC})$ and stable carbon isotope $\left(\delta^{13} \mathrm{C}\right)$ analyses were carried out on acidified samples (Ag capsules, $\mathrm{HCl}$, $1.5 \mathrm{M}$ ) to remove the carbonate fraction (Nieuwenhuize et al., 1994). Analyses were performed using a Thermo Electron mass spectrometer directly coupled to a Carlo Erba NC2500 elemental analyser via a Conflo III (Department of Geological Sciences, Stockholm University). OC values are reported as weight percent (wt \%) whereas stable isotope data are reported in the conventional $\delta^{13} \mathrm{C}$ notation (\%o). The analytical error for $\delta^{13} \mathrm{C}$ was lower than $\pm 0.1 \%$ based on replicates. Acidified $(\mathrm{HCl}, 1.5 \mathrm{M})$ samples for radiocarbon abundance 
were analysed at the US-NSF National Ocean Science Accelerator Mass Spectrometry (NOSAMS) facility (Woods Hole Oceanographic Institution, Woods Hole, USA). Radiocarbon data are reported in the standard $\Delta{ }^{14} \mathrm{C}$ notation (\%o).

Alkaline $\mathrm{CuO}$ oxidations were carried out using an UltraWAVE Milestone microwave as described by Tesi et al. (2014). Briefly, about $2 \mathrm{mg}$ of OC was oxidised using $\mathrm{CuO}$ under alkaline $(2 \mathrm{~N} \mathrm{NaOH})$ and oxygen-free conditions at $150{ }^{\circ} \mathrm{C}$ for $90 \mathrm{~min}$ in Teflon tubes. After the oxidation, known amounts of recovery standards (trans-cinnamic acid and ethylvanillin) were added to the solution. The $\mathrm{NaOH}$ solutions were then acidified to $\mathrm{pH} 1$ with concentrated $\mathrm{HCl}$ and extracted with ethyl acetate. Extracts were dried and redissolved in pyridine. $\mathrm{CuO}$ oxidation products were quantified by GC-MS in full scan mode $(50-650 \mathrm{~m} / \mathrm{z}$ ). Before $\mathrm{GC}$ analyses, the $\mathrm{CuO}$ oxidation products were derivatised with bis(trimethylsilyl)trifluoroacetamide $+1 \%$ trimethylchlorosilane at $60^{\circ} \mathrm{C}$ for $30 \mathrm{~min}$. The compounds were separated chromatographically in a $30 \mathrm{~m} \times 250 \mu \mathrm{m}$ DB5ms $(0.25 \mu \mathrm{m}$ thick film $)$ capillary GC column, using an initial temperature of $100^{\circ} \mathrm{C}$, a temperature ramp of $4{ }^{\circ} \mathrm{C} \mathrm{min}^{-1}$ and a final temperature of $300^{\circ} \mathrm{C}$. Lignin phenols (terrestrial biomarkers) were quantified using the response factors of commercially available standards (Sigma-Aldrich) whereas the rest of the $\mathrm{CuO}$ oxidation products were quantified by comparing the response factor of trans-cinnamic acid. Lignin-derived reaction products include vanillyl phenols (V: vanillin, acetovanillone, vanillic acid), syringyl phenols (S: syringealdehyde, acetosyringone, syringic acid) and cinnamyl phenols (C: $p$-coumaric acid, ferulic acid). In addition to lignin, cutin-derived products (hydroxyl fatty acids) were used to trace the land-derived input (Goñi and Hedges, 1990; Tesi et al., 2010). Other $\mathrm{CuO}$ oxidation products include para-hydroxybenzene monomers (P series), benzoic acids (B series) and short-chain fatty acids (FA series) which can have both terrestrial and marine origin (Goñi and Hedges, 1995; Tesi et al., 2010).

The sea ice proxy $\mathrm{IP}_{25}$ (monounsaturated highly branched isoprenoid (HBI) alkene) was quantified according to Belt et al. (2012). $\mathrm{IP}_{25}$ producers are a minor $(<5 \%)$ fraction of the total sea ice taxa which are, however, ubiquitous in pan-Arctic sea ice. Species include Pleurosigma stuxbergii var. rhomboide, Haslea crucigeroides (and/or Haslea spicula) and Haslea kjellmanii (Brown et al., 2014). Briefly, lipids were extracted via sonication using a dichloromethane/methanol solution $(2: 1 v / v \times 3)$. Prior to the extraction, two internal standards (7-hexylnonadecane, 7-HND; 9-octylheptadecene, 9-OHD) were added to permit quantification of $\mathrm{IP}_{25}$ (monounsaturated highly branched isoprenoid) following analysis via GC-MS. Total lipid extracts (TLEs) were dried under $\mathrm{N}_{2}$ after removing the water excess with anhydrous $\mathrm{NaSO}_{4}$. Dry TLEs were redissolved in dichloromethane and the non-polar hydrocarbon fraction was purified using open-column chromatography (deactivated $\mathrm{SiO}_{2}$ ) and hexane as eluent. Saturated and unsaturated n-alkanes were further separated using $10 \% \mathrm{AgNO}_{3}$ coated silica gel using hexane and dichloromethane, respectively.

Quantification of $\mathrm{IP}_{25}$ was carried out in SIM mode $(\mathrm{m} / z$ 350.3) as described in Belt et al. (2012). The GC was fitted with a $30 \mathrm{~m} \times 250 \mu \mathrm{m}$ DB5ms $(0.25 \mu \mathrm{m}$ thick film) capillary GC column. Initial GC oven temperature was set to $60^{\circ} \mathrm{C}$ followed by a $10^{\circ} \mathrm{C} \mathrm{min}^{-1}$ ramp until a final temperature of $310^{\circ} \mathrm{C}$ (hold time $10 \mathrm{~min}$ ).

\subsection{Microscope images of plankton}

High-resolution digital images were taken with an environmental scanning electron microscope (ESEM) Philips XL30 FEG in high voltage $(15 \mathrm{kV})$ and magnification $250 \times$. Samples were further studied for identification of diatoms and dinoflagellates using a transmitted-light microscope (Leitz Laborlux 12 Pol) equipped with differential interference contrast optics at $1000 \times$ magnification. Microscope slides were prepared using settling chambers to achieve an even distribution of particles on the cover glass, regardless of size and shape (Warnock and Scherer, 2015).

\subsection{Sea ice data}

Daily AMSR2 sea ice extent and concentration maps were provided by the Institute of Environmental Physics, University of Bremen, Germany (Spreen et al., 2008), as GeoTIFF files (https://seaice.uni-bremen.de/sea-ice-concentration/).

\subsection{Statistics}

We used two-tailed $t$ test (homoscedasticity) and Welch $t$ test (heteroscedasticity) to assess whether the differences between open waters and sea-ice-dominated waters were statistically significant. For this study, significance level (alpha) was set at 0.01 .

\section{Surface water conditions during the SWERUS-C3 expedition}

Before discussing the chemical composition of the POM $(>10 \mu \mathrm{m})$, here we briefly introduce the different environmental conditions encountered throughout the cruise track. The surface water data presented in this section were pulled together from previous studies which provide an in-depth analysis of the surface water properties during the SWERUSC3 expedition in 2014 (Humborg et al., 2017; Salvadó et al., 2016) (Table 2). For this study, continuous $p \mathrm{CO}_{2}$ aq and $\delta^{13} \mathrm{C}_{\mathrm{CO}_{2}}$ data (Humborg et al., 2017) were averaged to match the water sampling stations allowing for a direct comparison with DOC and salinity data (Fig. 2) (Supplement).

Summer 2014 was consistent with the long-term downward trend in Arctic sea ice extent. The strongest anomalies were observed in the LS which experienced the most northerly sea ice shift since satellite observations began in 


\section{Surface water properties}
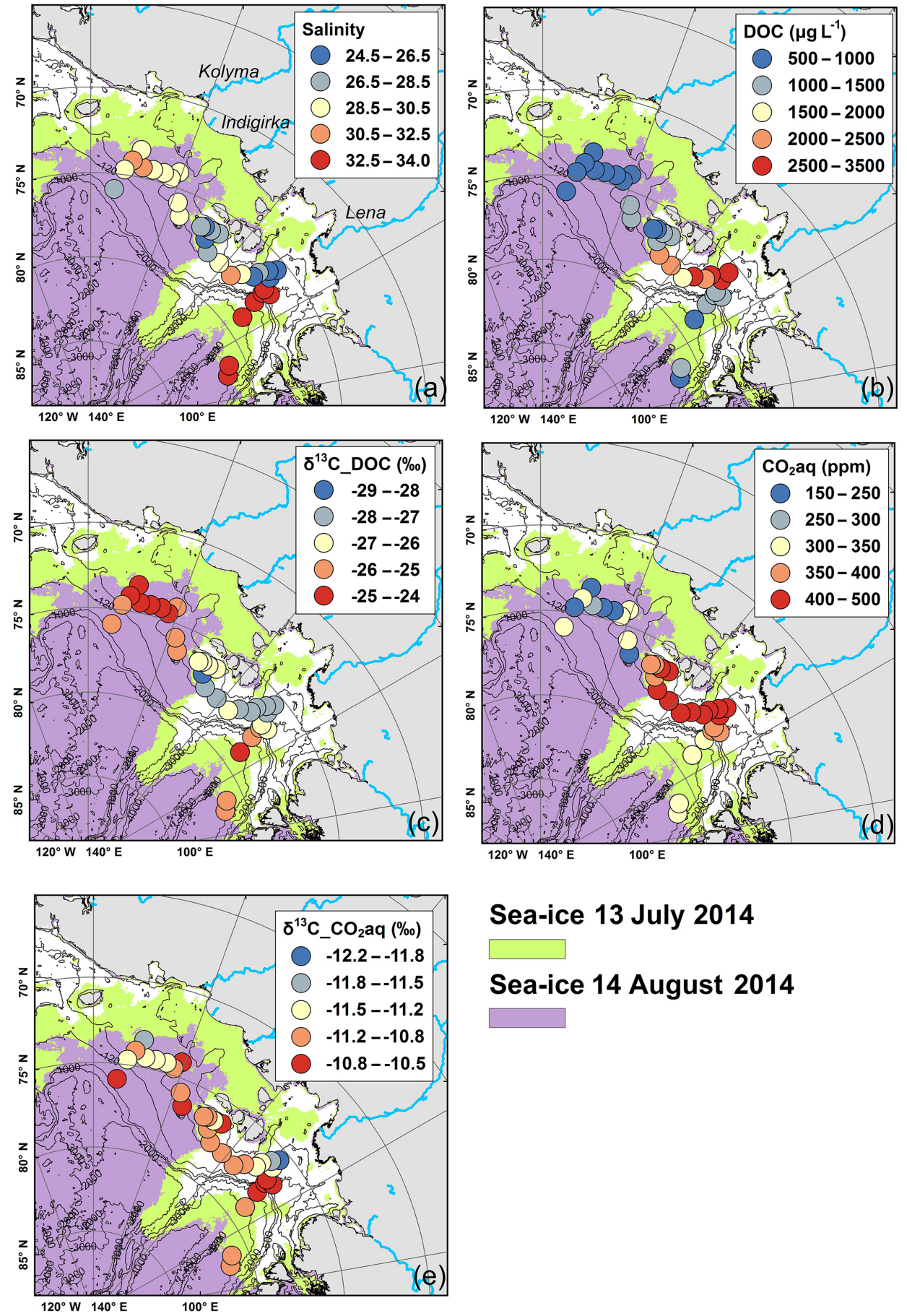

\section{Sea-ice 13 July 2014}

Sea-ice 14 August 2014

Figure 2. Surface water properties. (a) Salinity. (b) DOC. (c) $\delta^{13}$ C-DOC. (d) $\mathrm{CO}_{2}$ aq. (e) $\delta^{13} \mathrm{C}-\mathrm{CO}_{2}$ aq. Shaded areas show the sea ice extent at the beginning (13 July 2014) and at the end of the sampling campaign (14 August 2014) (Humborg et al., 2017; Salvadó et al., 2016).

1979 (National Snow and Sea Ice Data Center, NSIDC, http://nsidc.org/data, unpublished data). In general, sea ice displayed a strong gradient over the study region going from ice-free conditions in the outer LS to ice-dominated waters in the outer ESS (Fig. 1). Three snapshots of the sea ice extent and concentrations (i.e. at the beginning, in the middle and at the end of the sampling) is shown in Fig. 1. Furthermore, Table 1 reports the averaged sea ice concentrations encountered during the collection of each sample. 
Table 1. Chemical composition of the POM (> $10 \mu \mathrm{m})$ fraction and continuous $\mathrm{CO}_{2}$ aq measurements*

\begin{tabular}{|c|c|c|c|c|c|c|c|c|c|c|}
\hline ID & $\begin{array}{r}\text { Time-averaged } \\
\text { latitude }(\mathrm{N})\end{array}$ & $\begin{array}{r}\text { Time-averaged } \\
\text { longitude (E) }\end{array}$ & $\begin{array}{r}\text { Mean sea ice } \\
\text { percentage } \\
(\%)\end{array}$ & $\begin{array}{r}\text { POM }(>10 \mu \mathrm{m}) \\
\text { concentration } \\
\left(\mathrm{mg} \mathrm{L}^{-1}\right)\end{array}$ & $\begin{array}{r}\mathrm{OC} \\
(\mathrm{wt} \%)\end{array}$ & $\begin{array}{r}\delta^{13} \mathrm{C} \\
(\% o)\end{array}$ & $\begin{array}{r}\Delta^{14} \mathrm{C} \\
(\% \circ)\end{array}$ & $\begin{array}{r}\mathrm{IP} 25 \\
\left(\mathrm{ng} \mathrm{gOC}^{-1}\right)\end{array}$ & $\begin{array}{l}\text { Average } \\
\mathrm{CO}_{2} \mathrm{aq} \\
(\mathrm{ppm})^{*}\end{array}$ & $\begin{array}{r}\text { Average } \\
\delta^{13} \mathrm{C}^{-\mathrm{CO}_{2} \mathrm{aq}} \\
(\% \circ)^{*}\end{array}$ \\
\hline ST4 & 81.68 & 105.96 & 98.4 & 6 & 18.2 & -26.7 & n.d. & n.d. & 323 & -10.9 \\
\hline ST5 & 80.47 & 114.07 & 98.7 & 15 & 42.6 & -27.6 & n.d. & n.d. & 322 & -11.0 \\
\hline ST6 & 78.86 & 125.22 & 82.2 & 1 & 51.7 & -26.6 & 99 & n.d. & 325 & -10.8 \\
\hline ST7 & 77.88 & 126.62 & 0.0 & 11 & 43.1 & -25.7 & n.d. & 88 & 350 & -10.7 \\
\hline ST8 & 77.16 & 127.32 & 0.0 & 17 & 30.9 & -26.7 & 41 & n.d. & 391 & -10.5 \\
\hline ST11 & 77.12 & 126.66 & 0.0 & 13 & 29.6 & -28.1 & 27 & 13 & 428 & -10.7 \\
\hline ST22 & 77.67 & 144.63 & 0.0 & 20 & 11.3 & -28.8 & n.d. & 95 & 394 & -11.0 \\
\hline ST23 & 76.43 & 147.53 & 0.0 & 6 & 7.6 & -28.5 & -50 & n.d. & 394 & -11.2 \\
\hline ST24 & 76.42 & 149.84 & 34.4 & 19 & 11.9 & -26.8 & -62 & 368 & 374 & -11.1 \\
\hline ST25 & 76.62 & 152.03 & 96.7 & 23 & 19.5 & -25.7 & -31 & 465 & 263 & -10.8 \\
\hline ST26 & 76.14 & 157.85 & 96.2 & 109 & 30.8 & -24.2 & -30 & 217 & 316 & -10.9 \\
\hline ST31A & 75.85 & 174.41 & 75.6 & 30 & 10.9 & -21.6 & -62 & 1911 & 182 & -10.6 \\
\hline ST31B & 74.26 & 173.74 & 63.5 & 15 & 4.6 & -23.3 & n.d. & 783 & n.d. & n.d. \\
\hline ST32 & 73.56 & 176.06 & 51.8 & 21 & 11.3 & -24.5 & -58 & 131 & n.d. & n.d. \\
\hline ST33 & 72.35 & -175.14 & 0.0 & 20 & 15.5 & -23.5 & n.d. & 473 & n.d. & n.d. \\
\hline ST34 & 73.28 & -173.05 & 28.7 & 76 & 13.4 & -21.6 & -52 & 970 & n.d. & n.d. \\
\hline ST35 & 75.21 & -172.05 & 53.9 & 24 & 14.3 & -24.2 & n.d. & 268 & n.d. & n.d. \\
\hline
\end{tabular}

n.d.: not determined; ${ }^{*}$ Humborg et al. (2017).

The surface water salinity exhibited a longitudinal trend characterised by low values in the outer LS while the seaice-dominated ESS waters showed relatively higher values (Fig. 2a; Table 2). However, the highest salinity values were measured in the westernmost stations resulting in a sharp gradient in the LS. The low surface water salinities in the outer LS are most likely the result of both Lena River input and sea ice thawing (Humborg et al., 2017) that started in late May (Janout et al., 2016).

The highest DOC concentrations were measured in the mid-outer LS in the surface water plume affected by Lena River runoff (Fig. 2b; Table 2). Overall, DOC concentrations followed the plume dispersion with high DOC concentrations corresponding to low salinities (Fig. 2). Carbon stable isotopes $\left(\delta^{13} \mathrm{C}\right)$ and terrestrial biomarkers (of the solid-phase extracted DOC fraction; Salvadó et al., 2016) further confirmed the influence of terrestrial DOC in the outer LS, while the land-derived input progressively decreased moving eastward.

$p \mathrm{CO}_{2}$ aq concentrations exhibited a typical estuarine pattern over the study region (Humborg et al., 2017) (Fig. 2d; Table 2). Low-salinity waters in the outer LS showed above atmospheric $\mathrm{CO}_{2}$ concentrations (i.e. supersaturated) while surface waters below sea ice exhibited undersaturated concentrations. The most depleted $\delta^{13} \mathrm{C}_{\mathrm{CO}_{2}}$ values were measured off the Lena River mouth (Fig. 2e; Table 2). Being relatively rich in land-derived material, it is likely that respired terrestrial OC within the Lena River plume exerted control on the $\mathrm{CO}_{2}$ isotopic signature and concentration (Humborg et al., 2017).

Finally, nutrient distribution revealed nitrate $\left(\mathrm{NO}_{3}\right)$ depletion in surface waters throughout the cruise track (Humborg et al., 2017) in comparison with the Arctic Ocean gateways such as the Bering Strait. Here, nutrient concentrations in surface waters are 2 orders of magnitude higher compared to our study region (Torres-Valdés et al., 2013). Phosphate $\left(\mathrm{PO}_{4}\right)$ exhibited rather low concentrations in the outer LS and relatively higher concentrations below the sea ice in the outer ESS (Humborg et al., 2017), likely reflecting the inflow of nutrient-rich Pacific waters (Anderson et al., 2011; Semiletov et al., 2005; Torres-Valdés et al., 2013).

\section{Results and discussion}

\subsection{Source of the POM $(>10 \mu \mathrm{m})$ fraction}

The Arctic Ocean off northern Siberia receives large quantities of dissolved and particulate terrestrial organic carbon via continental runoff and coastal erosion (Alling et al., 2010; Dittmar and Kattner, 2003; McClelland et al., 2016; SánchezGarcía et al., 2011; Semiletov et al., 2013; Vonk et al., 2012). The land-derived material that does not settle in the coastal zone further travels across the continental margin reaching out to the outer-shelf region resuspended within the ben- 
Table 2. Surface water (0-20 m) chemical and physical properties during the SWERUS-C3 expedition*.

\begin{tabular}{|c|c|c|c|c|c|c|c|c|}
\hline & Salinity & $\begin{array}{r}\text { Temperature } \\
{ }^{\circ} \mathrm{C}\end{array}$ & $\begin{array}{r}\text { DIC } \\
\mu \mathrm{mol} \mathrm{kg}-1\end{array}$ & $\begin{array}{r}\text { DOC } \\
\mu \mathrm{mol} \mathrm{kg}\end{array}$ & $\begin{array}{r}\text { POC } \\
\mu \mathrm{mol} \mathrm{kg}\end{array}$ & $\begin{array}{r}\delta^{13} \mathrm{C}-\mathrm{DIC} \\
\% \circ\end{array}$ & $\begin{array}{r}\mathrm{NO}_{2}-\mathrm{NO}_{3} \\
\mu \mathrm{mol} \mathrm{kg}\end{array}$ & $\begin{array}{r}\mathrm{PO}_{4} \\
\mu \mathrm{mol} \mathrm{kg}\end{array}$ \\
\hline & median & median & median & median & median & median & median & median \\
\hline Outer LS shelf $(0-20 \mathrm{~m})$ & 32.87 & 3.84 & 2139 & 149.1 & 7.9 & 0.75 & 0.21 & 0.27 \\
\hline LS shelf break $(0-20 \mathrm{~m})$ & 33.56 & 0.57 & 2114 & 91.5 & 10.1 & 1.10 & 0.26 & 0.15 \\
\hline Outer ESS shelf $(0-20 \mathrm{~m})$ & 29.45 & -1.33 & 1969 & 84.2 & 10.7 & 1.14 & 0.25 & 0.97 \\
\hline \multirow[t]{2}{*}{ ESS shelf break $(0-20 \mathrm{~m})$} & 28.23 & -1.32 & 1979 & 73.7 & 4.6 & 1.47 & 0.11 & 0.59 \\
\hline & mean & mean & mean & mean & mean & mean & mean & mean \\
\hline Outer LS shelf $(0-20 \mathrm{~m})$ & 31.17 & 3.40 & 2119 & 179.8 & 7.9 & 0.58 & 0.60 & 0.29 \\
\hline LS shelf break $(0-20 \mathrm{~m})$ & 33.42 & 0.96 & 2111 & 97.5 & 10.0 & 1.10 & 0.61 & 0.16 \\
\hline Outer ESS shelf $(0-20 \mathrm{~m})$ & 28.95 & -0.05 & 1949 & 95.8 & 11.9 & 1.26 & 0.26 & 0.95 \\
\hline \multirow[t]{2}{*}{ ESS shelf break (0-20 m) } & 28.27 & -1.31 & 1975 & 72.0 & 4.6 & 1.49 & 0.12 & 0.60 \\
\hline & SD & SD & SD & SD & SD & SD & SD & SD \\
\hline Outer LS shelf $(0-20 \mathrm{~m})$ & 3.22 & 2.38 & 89 & 66.3 & 1.7 & 0.50 & 0.91 & 0.11 \\
\hline LS shelf break $(0-20 \mathrm{~m})$ & 0.70 & 2.07 & 23 & 21.2 & 1.7 & 0.11 & 0.74 & 0.06 \\
\hline Outer ESS shelf $(0-20 \mathrm{~m})$ & 1.41 & 2.28 & 75 & 30.2 & 4.6 & 0.49 & 0.12 & 0.19 \\
\hline ESS shelf break $(0-20 \mathrm{~m})$ & 0.53 & 0.04 & 49 & 3.2 & 0.3 & 0.08 & 0.03 & 0.02 \\
\hline
\end{tabular}

* Data from Humborg et al. (2017) and Salvadó et al. (2016).

thic nepheloid layer or in suspension within the surface river plume (Fichot et al., 2013; Sánchez-García et al., 2011; Wegner et al., 2003). Another fraction of terrestrial material can travel across the Siberian margin trapped in fast ice (Dethleff, 2005). Considering the potential allochthonous contribution, we addressed to what extent terrestrial organic material affects the POM $(>10 \mu \mathrm{m})$ fraction by quantifying the concentration of lignin phenols and C16-18 hydroxy fatty acids (cutin-derived products). These biomarkers are exclusively formed by terrestrial vegetation and, thus, serve as tracers of land-derived material in the marine environment (Amon et al., 2012; Bröder et al., 2016b; Feng et al., 2015).

Upon $\mathrm{CuO}$ alkaline oxidation the POM $(>10 \mu \mathrm{m})$ samples yielded only traces of lignin phenols while the cutin-derived products were not detected (Fig. 3). Other oxidation products in high abundance included saturated and monounsaturated short-chain fatty acids (C12-18FA), para-hydroxy phenols, benzoic acids and dicarboxylic acids. These other reaction products are ubiquitous in both marine and terrestrial environments but they are predominant in plankton-derived material, especially short-chain fatty acids (Goñi and Hedges, 1995). When compared with active-layer permafrost soils and ICDs (Tesi et al., 2014), POM (>10 $\mu \mathrm{m})$ samples displayed a distinct $\mathrm{CuO}$ fingerprint dominated by short-chain fatty acids (Fig. 3), consistent with the typical $\mathrm{CuO}$ products yields by phytoplankton batch cultures upon $\mathrm{CuO}$ alkaline oxidation (Goñi and Hedges, 1995). SEM images further corroborated the abundance of marine plankton detritus in the POM $(>10 \mu \mathrm{m})$ fraction while lithogenic particles (clastic material) appeared to be sporadic in all samples.
The OC content (wt \%) of the POM (>10 $\mu \mathrm{m})$ fraction decreased eastwards showing high concentrations in the LS and relatively low values in the ESS (Table $1 ; p<0.01 t$ test). However, in terms of absolute concentration in the water column $\left(\mu \mathrm{CL}^{-1}\right)$, the highest levels were generally observed in the sea-ice-covered region (Table 1; Fig. $4 \mathrm{a} ; p<0.01$ $t$ test). Qualitative analyses by SEM and transmitted-light microscopy highlight important differences in plankton assemblages which reflect different timing of the plankton blooms which can explain these differences in concentration. Specifically, the open-water LS stations exhibited a low degree of plankton diversity and were largely dominated by a bloom of heterotrophic dinoflagellate cysts (Protoperidinium spp.) (Fig. 5a; Table 3). Moving towards the ice-dominated regions, diatoms become the prevailing species. Dominant diatom genera include Chaetoceros spp. (dominant diatom in several stations), Thalassiosira spp., Rhizosolenia spp., Coscinodiscus spp., Asteromphalus spp., and Navicula spp. as well as sea ice species such as Fragilariopsis cylindrus and Fragilariopsis oceanica (Fig. 5b, c; Table 3).

Moored optical sensors deployed in the LS shelf recorded the sea ice retreat in 2014 and found no sign of pelagic underice blooms despite available nutrients while high chlorophyll concentrations were detected immediately after the ice retreated in late May (Janout et al., 2016). The ice-edge blooms lasted for about 2 weeks according to the high-resolution chlorophyll time series (Janout et al., 2016). Thus, our postbloom sampling in the LS essentially captured an oligotrophic environment dominated by heterotrophic dinoflagellate cysts (i.e. Protoperidinium spp.) which likely fed on 


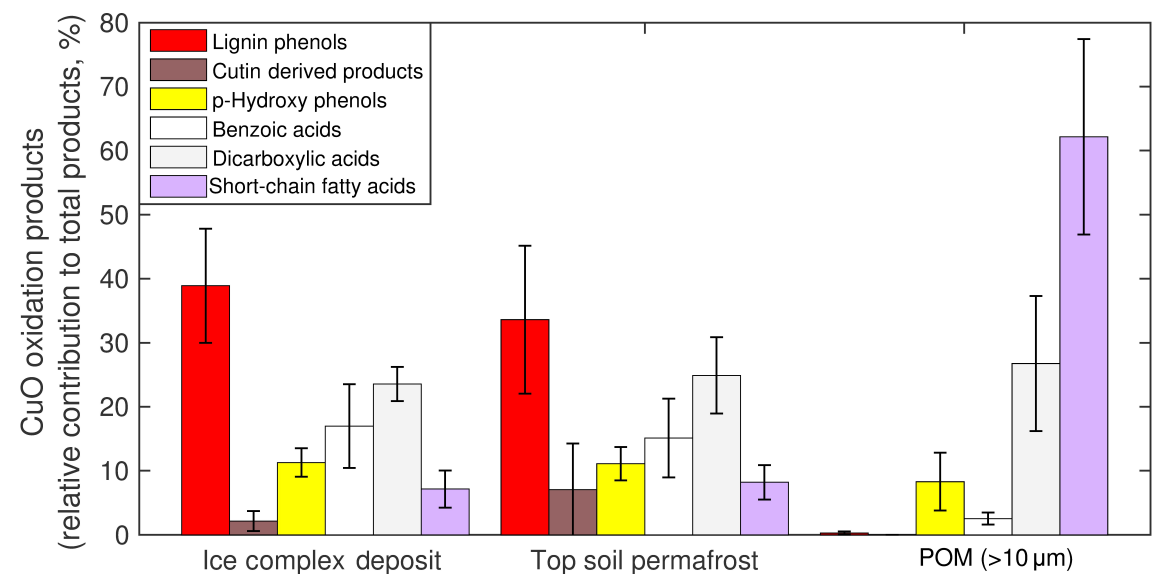

Figure 3. Alkaline $\mathrm{CuO}$ fingerprint of top-soil permafrost samples (Tesi et al., 2014), Pleistocene ice complex deposit (Tesi et al., 2014) and POM $(>10 \mu \mathrm{m})$ fraction (this study). The plot displays the relative proportion products yield upon alkaline CuO oxidation. The error bar refers to the natural variability of each dataset.
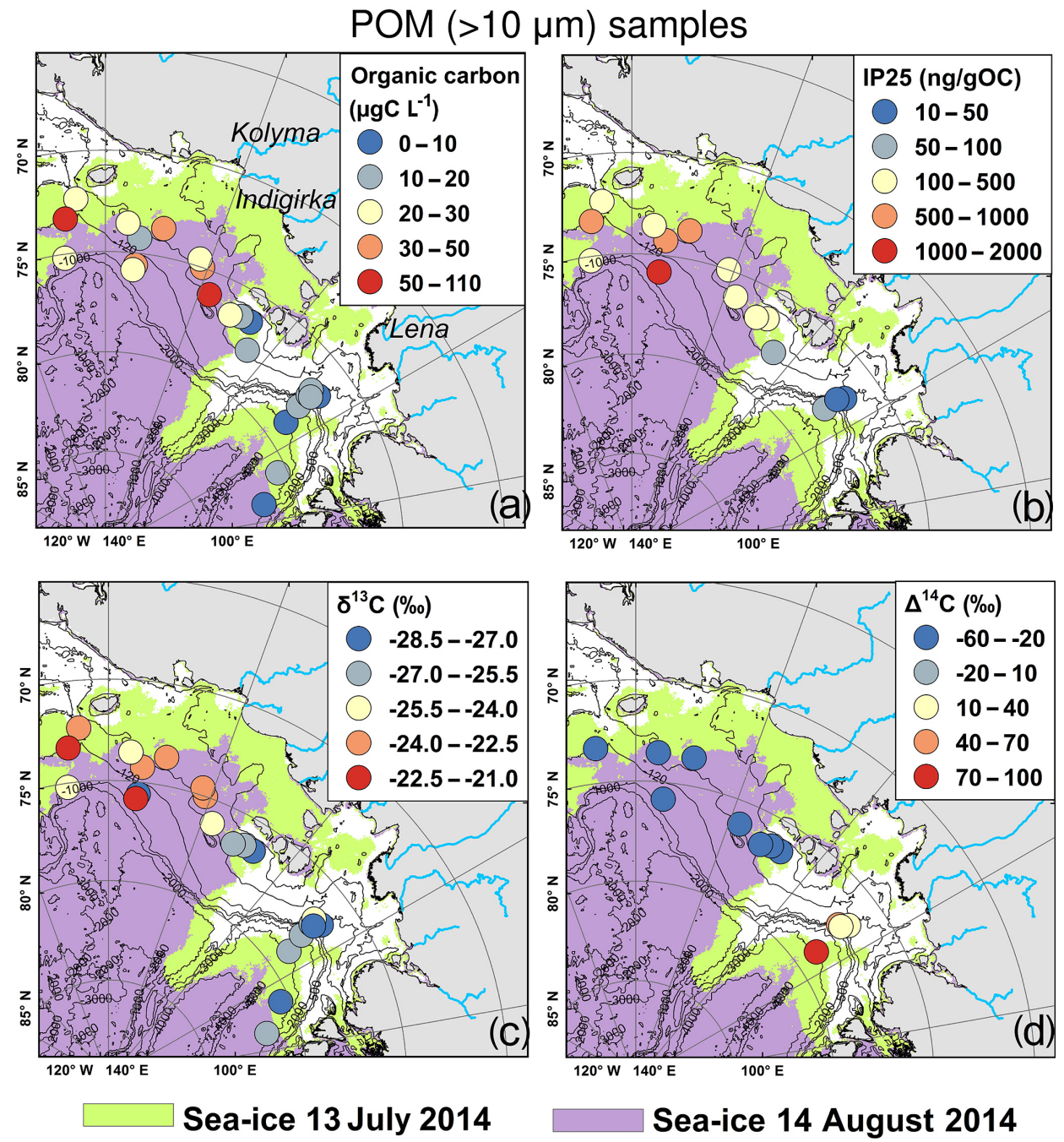

Figure 4. POM (> $10 \mu \mathrm{m}$ ) composition. (a) Organic carbon concentration. (b) IP25 (monounsaturated highly branched isoprenoid. (c) $\delta^{13} \mathrm{C}$. (d) $\Delta^{14} \mathrm{C}$. Shaded areas show the sea ice extent at the beginning (13 July 2014) and at the end of the sampling campaign (14 August 2014). 
Table 3. Qualitative plankton characterisation of selected POM (>10 $\mu \mathrm{m})$ samples.

\begin{tabular}{|c|c|c|c|c|}
\hline ID & Region & Diatoms & Dinoflagellates & Other species \\
\hline ST6 & LS & Few Coscinodiscus & None observed & \\
\hline ST9 & $\mathrm{LS}$ & None observed & Few Protoperidinium & \\
\hline ST11 & $\mathrm{LS}$ & None observed & Abundant Protoperidinium & \\
\hline ST22 & LS-ESS & $\begin{array}{l}\text { Abundant Chaetoceros, few Rhizosolenia, } \\
\text { Thalassiosira }\end{array}$ & None observed & \\
\hline ST25 & LS-ESS & $\begin{array}{l}\text { High diversity; abundant Chaetoceros, few } \\
\text { Rhizosolenia, Coscinodiscus, Thalassiosira, } \\
\text { Asteromphalus, Navicula }\end{array}$ & None observed & Silicoflagellate \\
\hline ST31A & ESS & $\begin{array}{l}\text { High diversity; abundant Chaetoceros, few } \\
\text { Rhizosolenia, Thalassiosira, Bacterosira, } \\
\text { Navicula }\end{array}$ & None observed & \\
\hline ST31B & ESS & $\begin{array}{l}\text { High diversity; few Chaetoceros, Thalassiosira, } \\
\text { Fragilariopsis }\end{array}$ & Few Protoperidinium & \\
\hline ST34 & ESS & $\begin{array}{l}\text { Abundant Chaetoceros, few Thalassiosira, } \\
\text { Navicula }\end{array}$ & Few Protoperidinium & \\
\hline
\end{tabular}

phytodetritus and river-derived organic material. Such conditions are fairly consistent with the relatively low carbon contents $\left(\mu \mathrm{g} \mathrm{C} \mathrm{L}^{-1}\right)$ observed in LS waters (Fig. 4a).

The Arctic sea ice biomarker IP25 (Fig. 4b) further highlights the different regimes observed in ice-free and icedominated surface waters. IP25 is a proxy of sea ice based on a highly branched monounsaturated isoprenoid alkene found in some sea ice diatoms which, however, generally account for $5 \%$ of the total sea ice taxa (Belt et al., 2007; Brown et al., 2014). The IP25 concentrations varied by several orders of magnitude over the study area showing low concentrations in the open-water western region while the sea-ice-dominated surface waters to the east exhibited high concentrations especially at station $31 \mathrm{~b}$ (Fig. 4b; Table 1); $p<0.01$ Welch $t$ test). The fact that IP25 was still detectable throughout the icefree outer LS suggests that the proxy captured the signal of the sea ice retreat that occurred shortly before the sampling at the end of May/early June (Janout et al., 2016). Alternatively, the IP25 could have been advected from nearby seaice-dominated regions.

\subsection{Dual carbon isotopes: $\delta^{13} \mathrm{C}$ and $\Delta^{14} \mathrm{C}$}

$\delta^{13} \mathrm{C}$ and $\Delta^{14} \mathrm{C}$ of the POM (>10 $\left.\mu \mathrm{m}\right)$ samples exhibited a distinctive longitudinal trend across the study area between LS and ESS (Fig. 4c, d) $\left(p<0.01 t\right.$ test). Depleted $\delta^{13} \mathrm{C}$ values characterised the LS open waters ranging from -28.1 to $-24.7 \%$ (Fig. 4c). Although within the range of terrestrially derived material, our $\mathrm{CuO}$ oxidation data (i.e. trace of lignin phenols and absence of cutin-derived products) suggest that the "light" isotopic composition in the LS might instead reflect the plankton assemblage dominated by heterotrophic dinoflagellate cysts as previously described (e.g. Protoperidinium spp.; Fig. 5a). More specifically, heterotrophic dinoflagellates can adapt their metabolism depending on the
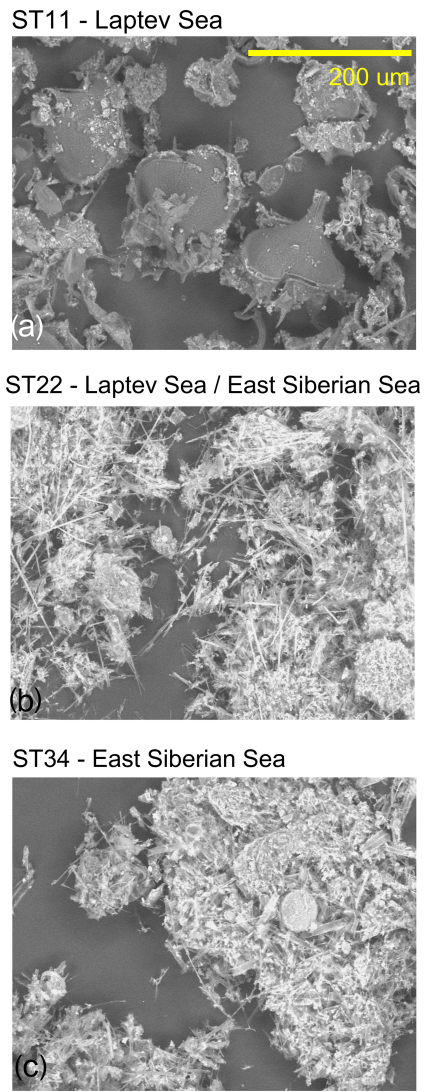

Figure 5. SEM images. (a) ST-11: dinoflagellates (Protoperidinium spp.) in open waters of the Laptev Sea. (b) ST22: diatoms, mostly spines (setae) of Chaetoceros spp. in the transition between Laptev Sea and East Siberian Sea. (c) ST-34: diatoms from sea-icedominated waters in the East Siberian Sea. 


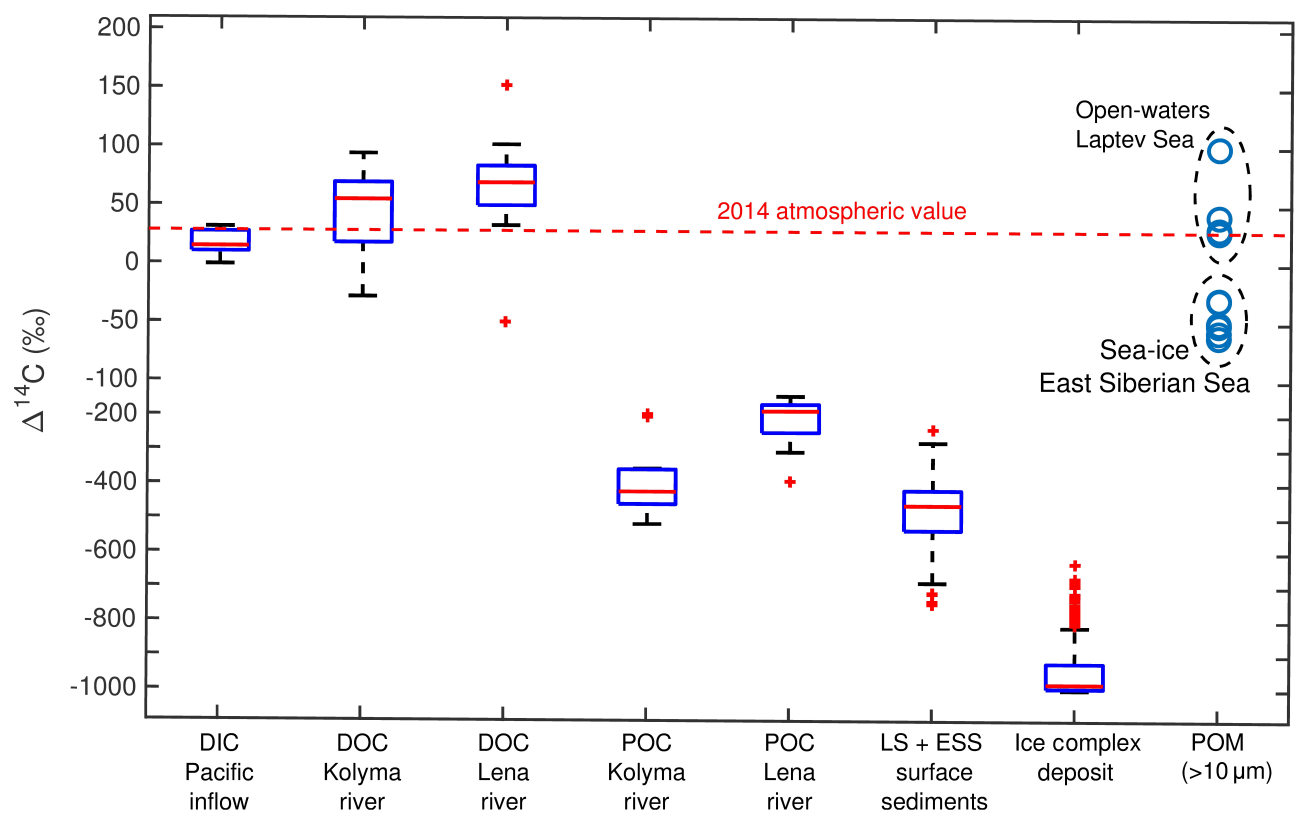

Figure 6. Radiocarbon signature of inorganic and organic carbon pools. Whisker plots of radiocarbon values for different inorganic and organic carbon sources from the literature, compared to the outer Laptev Sea and outer East Siberian Sea (blue circles, this study). Solid lines show the median, the box limits display the 25th and 75th percentiles, and the crosses show the outliers. Source: DIC (Griffith et al., 2012), DOC-Kolyma (2009-2014), DOC-Lena (2009-2014), POC-Kolyma (2009-2011), POC-Lena (2009-2011) (http://www.arcticgreatrivers. org), Laptev Sea and East Siberia Sea surface sediments (Salvadó et al., 2016; Vonk et al., 2012) and ICD (Vonk et al., 2012).

substrate available (e.g. diatoms and bacteria). Several studies have shown that terrestrial DOC greatly promotes bacteria biomass production which in turn stimulates the growth of heterotrophic dinoflagellates (Carlsson et al., 1995; Purina et al., 2004; Wikner and Andersson, 2012). Thus, in these conditions, allochthonous terrestrial DOC is actively recycled by bacteria and transferred to dinoflagellates which explains, thus, the depleted $\delta^{13} \mathrm{C}$ values observed in the riverdominated samples (Carlsson et al., 1995).

The modern radiocarbon fingerprint of the Lena DOC discharge is consistent with $\Delta^{14} \mathrm{C}$ signature of the POM $(>10 \mu \mathrm{m})$ fraction in the LS (up to $+99 \%$ ), supporting the importance of terrestrial DOC as a carbon source for the food web in the river plume (Figs. 4d and 6). By contrast, comparison with other potential carbon sources which include the Lena River particulate organic carbon, surface sediments, Pleistocene coastal ICD and Pacific DIC inflow reveals a different (more depleted) radiocarbon fingerprint (Fig. 6). It is also important to highlight that the DOC within the Lena plume is 1-2 orders of magnitude higher than the particulate carbon pool, thus supporting our hypothesis (Humborg et al., 2017; Salvadó et al., 2016).

Moving towards the ice-dominated ESS, surface waters progressively became more autotrophic and productive (Humborg et al., 2017) while the POM $(>10 \mu \mathrm{m})$ exhibited a wide $\delta^{13} \mathrm{C}$ signature ranging from -28.6 to $-21.2 \%$ (Fig. 4c). The most depleted values were observed across the transition zone between open waters and sea ice. Visual in- spections of these samples revealed large abundance of the centric diatom Chaetoceros spp. (spores and vegetative cells; St22, Fig. 5b) while lignin and cutin data indicated, a negligible input of land-derived material. Primary factors determining the fractionation of stable carbon isotopes in phytoplankton are several and include $\mathrm{CO}_{2}$ aq concentration, $\delta^{13} \mathrm{Caq}$, growth rate, cell size, cell shape, light and nutrient availability (Gervais and Riebesell, 2001; Laws et al., 1997b; Popp et al., 1998; Rau et al., 1996). Our understanding about isotopic fractionation has been historically achieved via laboratory experiments designed to test each factor under controlled conditions. In natural environments, however, different factors can compete with each other, sometimes in opposite directions. Yet, the existing knowledge about surface water properties during the expedition (Humborg et al., 2017) can provide important constraints for the isotopic signal interpretation.

For example, comparison with continuous $\delta^{13} \mathrm{C}^{-\mathrm{CO}_{2} \mathrm{aq}}$ and $p \mathrm{CO}_{2}$ aq data measured throughout the cruise track time-averaged to match the large-volume filtration along the cruise track (Table 1) - suggested a negligible role exerted by $\delta^{13} \mathrm{C}-\mathrm{CO}_{2}$ aq (Fig. 7b) while $p \mathrm{CO}_{2}$ aq concentration correlated with the $\delta^{13} \mathrm{C}$ of the POM $(>10 \mu \mathrm{m})$ fraction $\left(r^{2}=\right.$ $0.72 ; p<0.01$ ) (Fig. 7a). Such a relationship fits with the general model according to which a low demand (i.e. low growth rate) and high supply (i.e. abundant $\mathrm{CO}_{2}$ aq) favour high fractionation and vice versa (Laws et al., 1997a, 1995; Wolf-Gladrow et al., 1999). 

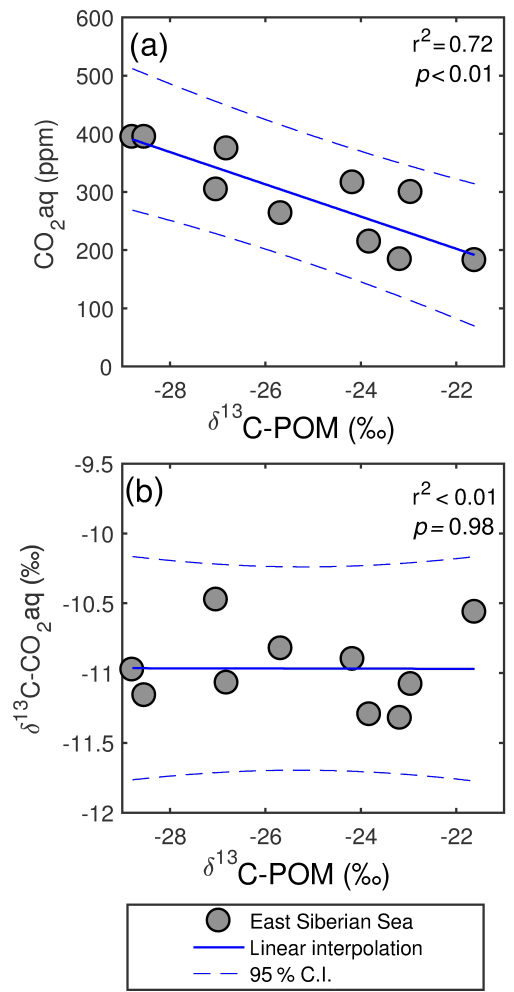

Figure 7. Correlations (a) $\mathrm{CO}_{2}$ aq versus $\delta^{13} \mathrm{C}$ (POM (>10 $\left.\mu \mathrm{m}\right)$ fraction) and (b) $\delta^{13} \mathrm{C}-\mathrm{CO}_{2}$ aq versus $\delta^{13} \mathrm{C}$ in the East Siberian Sea (filled circles). The solid line shows the linear interpolation while the dashed line shows the $95 \%$ confidence intervals.

During the expedition, surface water properties (i.e. $\mathrm{O}_{2}$ and $\mathrm{CO}_{2}$, Table 2) (Humborg et al., 2017) suggest that the productivity in the outer ESS increases moving eastward, as commonly observed, likely due to the Pacific inflow (Anderson et al., 2011; Semiletov et al., 2005). As a result, the wide range of plankton $\delta^{13} \mathrm{C}$ over the ESS can be explained in terms of two different regimes: (a) in the transition zone between open waters and sea ice, the productivity was low but $p \mathrm{CO}_{2}$ aq was supersaturated, while (b) in the easternmost ESS, productivity was high but $p \mathrm{CO}_{2}$ aq was depleted (Fig. 7b). The former regime favours fractionation while the latter does not (Fig. 7b). Different diatom assemblages can also be another factor to consider although the phytoplankton diversity observed over ESS can be considered rather small (e.g. Chaetoceros spp. dominant in most of the samples) compared to the wide range of $\delta^{13} \mathrm{C}$ observed (i.e. from -28.8 to -21.6 ) (Table 3).

The POM $(>10 \mu \mathrm{m})$ fraction in the sea-ice-dominated ESS exhibited slightly - but consistently - depleted $\Delta^{14} \mathrm{C}$ values ranging from -62 to $-49 \%$ (Fig. $4 \mathrm{~d}$ ). This region is affected by the inflow of Pacific waters whose DIC exhibits, however, a modern $\Delta^{14} \mathrm{C}$ signature (Griffith et al., 2012) (Fig. 6). By contrast, these results suggest the influence from an aged carbon pool. As the ESS remains covered by sea ice for most of the year, it is possible that the sea ice hampers the gas exchange with the atmosphere and acts as a lid by trapping $\mathrm{CO}_{2}$ which derives from the breakdown of sedimentary organic material (Anderson et al., 2009; Semiletov et al., 2016), which might have such ages (Bröder et al., 2016a; Vonk et al., 2012). In these conditions, the pre-aged $\mathrm{CO}_{2}$ accumulates underneath the sea ice and is subsequently incorporated during carbon fixation by the phytoplankton. While supersaturated bottom waters were extensively documented in the region with important consequences on the local DIC (Anderson et al., 2009; Pipko et al., 2009), more work is clearly needed to understand whether early diagenesis in sediments can also affect the radiocarbon signature of the $\mathrm{CO}_{2}$ aq underneath the sea ice. Alternatively, the slightly depleted radiocarbon signature might indicate the presence of pre-aged terrestrial organic carbon (Fig. 6) in the POM (>10 $\mu \mathrm{m})$ samples, not reflected in the lignin and cutin tracers (Fig. 3). However, it would then remain elusive why such an aged land-derived influence was not visible in the river-dominated LS waters while it affected the sea-ice-dominated region.

Taken together, our results indicate that the dual-carbon isotope fingerprint is highly affected by the trophic conditions (heterotrophic vs. autotrophic) as well as the extent of primary productivity. In a warming scenario characterised by sea ice retreat (Arrigo et al., 2008; Comiso et al., 2008) and enhanced terrestrial input from land as a result of hydrology and permafrost destabilisation (Frey and Smith, 2005; Vonk et al., 2012), the geochemical composition of plankton will likely change as the warming proceeds.

\section{Conclusions}

Analyses of large-volume filtrations of plankton-dominated $>10 \mu \mathrm{m}$ particle samples revealed a high degree of heterogeneity in the dual-carbon isotope signature $\left(\delta^{13} \mathrm{C}\right.$ and $\left.\Delta^{14} \mathrm{C}\right)$ between ice-free waters (Laptev Sea) and the ice-covered region (East Siberian Sea).

Our results suggest a heterotrophic environment in the outer LS open waters where the $\delta^{13} \mathrm{C}$-depleted river DOC is transferred to relatively higher trophic levels via microbial incorporation in the river plume. Moving eastwards towards the ice-dominated outer ESS, surface waters became progressively more autotrophic. Here, the isotopic fractionation appears to follow the phytoplankton growth versus $\mathrm{CO}_{2}$ demand model according to which carbon fractionation decreases at high growth and low $\mathrm{CO}_{2}$ concentrations. As a result, the transition between open waters and sea ice exhibited more depleted $\delta^{13} \mathrm{C}$ values compared to the productive easternmost stations. Radiocarbon signatures were slightly depleted over the whole sea-ice-dominated area. This raises the question of whether the sea ice hampers the gas exchange with the atmosphere and traps the $\mathrm{CO}_{2}$ sourced from reactive sedimentary carbon pools. 
In a warming scenario, it is likely that the oligotrophic ice-free LS will be dominated by heterotrophic metabolism fuelled by terrestrially derived organic material (i.e. Lena input). In these conditions, the dual-carbon isotope signature of the heterotrophic plankton will essentially reflect the terrestrial fingerprint. In the ESS, which receives the inflow of the nutrient-rich Pacific waters, ice-free conditions will enhance light penetration. This in turn might further stimulate phytoplankton growth with important implications in terms of $\mathrm{CO}_{2}$ depletion and resulting low isotope fractionation. Altogether, this will result in a sharp compositional gradient (e.g. $\delta^{13} \mathrm{C}$ ) between LS and ESS, similar to what was captured in our semi-synoptic study.

Data availability. All data presented in this study are to be found in the tables.

\section{The Supplement related to this article is available online at https://doi.org/10.5194/os-13-735-2017-supplement.}

Competing interests. The authors declare that they have no conflict of interest.

Special issue statement. This article is part of the special issue "Climate-carbon-cryosphere interactions in the East Siberian Arctic Ocean: past, present and future (TC/BG/CP/OS inter-journal $\mathrm{SI})$ ". It is not associated with a conference.

Acknowledgements. We thank the I/B Oden crew and the Swedish Polar Research Secretariat staff. This study was supported by the Knut and Alice Wallenberg Foundation (KAW contract 2011.0027), the Swedish Research Council (VR contract 621-2007-4631 and 621-2013-5297) and the European Research Council (ERC-AdG CC-TOP project \#695331 to Örjan Gustafsson). Tommaso Tesi additionally acknowledges EU financial support as Marie Curie fellow (contract no. PIEF-GA-2011-300259). Joan A. Salvado acknowledges EU financial support through a Marie Curie grant (contract no. FP7-PEOPLE-2012-IEF; project 328049). Igor Semiletov acknowledges financial support from the Russian Government (grant no. 14, Z50.31.0012/03.19.2014) and the Russian Foundation for Basic Research (nos. 13-05-12028 and 13-05-12041), and Elena Panova from the Russian Scientific Foundation (grant no. 15-17-20032). We thank the Arctic Great Rivers Observatory (NSF-1107774) for providing DOC and POC river data (http://www.arcticgreatrivers.org). This is ISMAR publication ID n.1940.

Edited by: Leif Anderson

Reviewed by: two anonymous referees

\section{References}

Aagaard, K. and Carmack, E. C.: The role of sea ice and other fresh water in the Arctic circulation, J. Geophys. Res.-Oceans, 94, 14485-14498, 1989.

Alling, V., Sanchez-Garcia, L., Porcelli, D., Pugach, S., Vonk, J. E., van Dongen, B., Mörth, C.-M., Anderson, L. G., Sokolov, A., Andersson, P., Humborg, C., Semiletov, I., and Gustafsson, Ö.: Nonconservative behavior of dissolved organic carbon across the Laptev and East Siberian seas, Global Biogeochem. Cy., 24, https://doi.org/10.1029/2010GB003834, 2010.

Amon, R., Rinehart, A., Duan, S., Louchouarn, P., Prokushkin, A., Guggenberger, G., Bauch, D., Stedmon, C., Raymond, P., and Holmes, R.: Dissolved organic matter sources in large Arctic rivers, Geochim. Cosmochim. Ac., 94, 217-237, 2012.

Anderson, L. G., Jutterström, S., Hjalmarsson, S., Wåhlström, I., and Semiletov, I.: Out-gassing of $\mathrm{CO}_{2}$ from Siberian Shelf seas by terrestrial organic matter decomposition, Geophys. Res. Lett., 36, https://doi.org/10.1029/2009GL040046, 2009.

Anderson, L. G., Björk, G., Jutterström, S., Pipko, I., Shakhova, N., Semiletov, I., and Wåhlström, I.: East Siberian Sea, an Arctic region of very high biogeochemical activity, Biogeosciences, 8 , 1745-1754, https://doi.org/10.5194/bg-8-1745-2011, 2011.

Ardyna, M., Babin, M., Gosselin, M., Devred, E., Rainville, L., and Tremblay, J. É.: Recent Arctic Ocean sea ice loss triggers novel fall phytoplankton blooms, Geophys. Res. Lett., 41, 6207-6212, 2014.

Arrigo, K. R., van Dijken, G., and Pabi, S.: Impact of a shrinking Arctic ice cover on marine primary production, Geophys. Res. Lett., 35, https://doi.org/10.1029/2008GL035028, 2008.

Belt, S. T., Massé, G., Rowland, S. J., Poulin, M., Michel, C., and LeBlanc, B.: A novel chemical fossil of palaeo sea ice: IP25, Org. Geochem., 38, 16-27, 2007.

Belt, S. T., Brown, T. A., Rodriguez, A. N., Sanz, P. C., Tonkin, A., and Ingle, R.: A reproducible method for the extraction, identification and quantification of the Arctic sea ice proxy IP25 from marine sediments, Anal. Method., 4, 705-713, 2012.

Bröder, L., Tesi, T., Andersson, A., Eglinton, T. I., Semiletov, I. P., Dudarev, O. V., Roos, P., and Gustafsson, Ö.: Historical records of organic matter supply and degradation status in the East Siberian Sea, Org. Geochem., 91, 16-30, 2016 a.

Bröder, L., Tesi, T., Salvadó, J. A., Semiletov, I. P., Dudarev, O. V., and Gustafsson, Ö.: Fate of terrigenous organic matter across the Laptev Sea from the mouth of the Lena River to the deep sea of the Arctic interior, Biogeosciences, 13, 5003-5019, https://doi.org/10.5194/bg-13-5003-2016, 2016 b.

Brown, T. A., Belt, S. T., Tatarek, A., and Mundy, C. J.: Source identification of the Arctic sea ice proxy IP25, 5, 4197, https://doi.org/10.1038/ncomms5197, 2014.

Carlsson, P., Graneli, E., Tester, P., and Boni, L.: Influences of riverine humic substances on bacteria, protozoa, phytoplankton, and copepods in a coastal plankton community, Mar. Ecol.-Prog. Ser., 127, 213-221, 1995.

Comiso, J. C., Parkinson, C. L., Gersten, R., and Stock, L.: Accelerated decline in the Arctic sea ice cover, Geophys. Res. Lett., 35, https://doi.org/10.1029/2007GL031972, 2008.

Dethleff, D.: Entrainment and export of Laptev Sea ice sediments, Siberian Arctic, J. Geophys. Res.-Oceans, 110, https://doi.org/10.1029/2004JC002740, 2005. 
Ding, Q., Schweiger, A., Lheureux, M., Battisti, D. S., Po-Chedley, S., Johnson, N. C., Blanchard-Wrigglesworth, E., Harnos, K., Zhang, Q., Eastman, R., and Steig, E. J.: Influence of highlatitude atmospheric circulation changes on summertime Arctic sea ice, Nature Clim. Change, 7, 289-295, 2017.

Dittmar, T. and Kattner, G.: The biogeochemistry of the river and shelf ecosystem of the Arctic Ocean: a review, Mar. Chem., 83, 103-120, 2003.

Dunton, K. H., Weingartner, T., and Carmack, E. C.: The nearshore western Beaufort Sea ecosystem: Circulation and importance of terrestrial carbon in arctic coastal food webs, Prog. Oceanogr., 71, 362-378, 2006.

Feng, X., Gustafsson, Ö., Holmes, R. M., Vonk, J. E., van Dongen, B. E., Semiletov, I. P., Dudarev, O. V., Yunker, M. B., Macdonald, R. W., Wacker, L., Montluçon, D. B., and Eglinton, T. I.: Multimolecular tracers of terrestrial carbon transfer across the pan-Arctic: $14 \mathrm{C}$ characteristics of sedimentary carbon components and their environmental controls, Global Biogeochem. Cy., 29, 1855-1873, 2015.

Fichot, C. G., Kaiser, K., Hooker, S. B., Amon, R. M., Babin, M., Bélanger, S., Walker, S. A., and Benner, R.: Pan-Arctic distributions of continental runoff in the Arctic Ocean, Sci. Rep., 3, 1053, https://doi.org/10.1038/srep01053, 2013.

Frey, K. E. and Smith, L. C.: Amplified carbon release from vast West Siberian peatlands by 2100 , Geophys. Res. Lett., 32, https://doi.org/10.1029/2004GL022025, 2005.

Fujiwara, A., Hirawake, T., Suzuki, K., Imai, I., and Saitoh, S.I.: Timing of sea ice retreat can alter phytoplankton community structure in the western Arctic Ocean, Biogeosciences, 11, 17051716, https://doi.org/10.5194/bg-11-1705-2014, 2014.

Gervais, F. and Riebesell, U.: Effect of phosphorus limitation on elemental composition and stable carbon isotope fractionation in a marine diatom growing under different $\mathrm{CO}_{2}$ concentrations, Limnol. Oceanogr., 46, 497-504, 2001.

Goñi, M. A. and Hedges, J. I.: Potential applications of cutinderived $\mathrm{CuO}$ reaction products for discriminating vascular plant sources in natural environments, Geochim. Cosmochim. Ac., 54, 3073-3081, 1990.

Goñi, M. A. and Hedges, J. I.: Sources and reactivities of marinederived organic matter in coastal sediments as determined by alkaline $\mathrm{CuO}$ oxidation, Geochim. Cosmochim. Ac., 59, 29652981, 1995.

Gordeev, V. V.: Fluvial sediment flux to the Arctic Ocean, Geomorphology, 80, 94-104, 2006.

Griffith, D. R., McNichol, A. P., Xu, L., McLaughlin, F. A., Macdonald, R. W., Brown, K. A., and Eglinton, T. I.: Carbon dynamics in the western Arctic Ocean: insights from full-depth carbon isotope profiles of DIC, DOC, and POC, Biogeosciences, 9, 1217-1224, https://doi.org/10.5194/bg-9-1217-2012, 2012.

Gustafsson, Ö. and Andersson, P. S.: 234Th-derived surface export fluxes of POC from the Northern Barents Sea and the Eurasian sector of the Central Arctic Ocean, Deep-Sea Res. Pt. I, 68, 1-11, 2012.

Gustafsson, Ö., Andersson, P., Axelman, J., Bucheli, T., Kömp, P., McLachlan, M., Sobek, A., and Thörngren, J.-O.: Observations of the PCB distribution within and in-between ice, snow, icerafted debris, ice-interstitial water, and seawater in the Barents Sea marginal ice zone and the North Pole area, Sci. Total Environ., 342, 261-279, 2005.
Hoins, M., Van de Waal, D. B., Eberlein, T., Reichart, G.-J., Rost, B., and Sluijs, A.: Stable carbon isotope fractionation of organic cyst-forming dinoflagellates: Evaluating the potential for a $\mathrm{CO}_{2}$ proxy, Geochim. Cosmochim. Ac., 160, 267-276, 2015.

Humborg, C., Geibel, M. C., Anderson, L. G., Björk, G., Mörth, C.-M., Sundbom, M., Thornton, B. F., Deutsch, B., Gustafsson, E., Gustafsson, B., Ek, J., and Semiletov, I.: Sea-air exchange patterns along the central and outer East Siberian Arctic Shelf as inferred from continuous $\mathrm{CO}_{2}$, stable isotope and bulk chemistry measurements, Global Biogeochem. Cy., 31, https://doi.org/10.1002/2017GB005656, 2017.

Iken, K., Bluhm, B., and Gradinger, R.: Food web structure in the high Arctic Canada Basin: evidence from $\delta^{13} \mathrm{C}$ and $\delta^{15} \mathrm{~N}$ analysis, Polar Biol., 28, 238-249, 2005.

Janout, M. A., Hölemann, J., Waite, A. M., Krumpen, T., Appen, W. J., and Martynov, F.: Sea-ice retreat controls timing of summer plankton blooms in the Eastern Arctic Ocean, Geophys. Res. Lett., 43, https://doi.org/10.1002/2016GL071232, 2016.

Karlsson, E., Gelting, J., Tesi, T., Dongen, B., Andersson, A., Semiletov, I., Charkin, A., Dudarev, O., and Gustafsson, Ö.: Different sources and degradation state of dissolved, particulate and sedimentary organic matter along the Eurasian Arctic coastal margin, Global Biogeochem. Cy., 6, https://doi.org/10.1002/2015GB005307, 2016.

Kohlbach, D., Graeve, M., A Lange, B., David, C., Peeken, I., and Flores, H.: The importance of ice algae-produced carbon in the central Arctic Ocean ecosystem: Food web relationships revealed by lipid and stable isotope analyses, Limnol. Oceanogr., 61, https://doi.org/10.1002/lno.10351, 2016.

Kwok, R. and Rothrock, D.: Decline in Arctic sea ice thickness from submarine and ICESat records: 1958-2008, Geophys. Res. Lett., 36, https://doi.org/10.1029/2009GL039035, 2009.

Lalande, C., Bélanger, S., and Fortier, L.: Impact of a decreasing sea ice cover on the vertical export of particulate organic carbon in the northern Laptev Sea, Siberian Arctic Ocean, Geophys. Res. Lett., 36, https://doi.org/10.1029/2009GL040570, 2009.

Lalande, C., Nöthig, E. M., Somavilla, R., Bauerfeind, E., Shevchenko, V., and Okolodkov, Y.: Variability in under-ice export fluxes of biogenic matter in the Arctic Ocean, Global Biogeochem. Cy., 28, 571-583, 2014.

Lantuit, H., Atkinson, D., Paul Overduin, P., Grigoriev, M., Rachold, V., Grosse, G., and Hubberten, H.-W.: Coastal erosion dynamics on the permafrost-dominated Bykovsky Peninsula, north Siberia, 1951-2006, Polar Res., 30, 7341, https://doi.org/10.3402/polar.v30i0.7341, 2011.

Laws, E. A., Popp, B. N., Bidigare, R. R., Kennicutt, M. C., and Macko, S. A.: Dependence of phytoplankton carbon isotopic composition on growth rate and $\left(\mathrm{CO}_{2}\right)$ aq: Theoretical considerations and experimental results, Geochim. Cosmochim. Ac., 59, 1131-1138, 1995.

Laws, E. A., Bidigare, R. R., and Popp, B. N.: Effect of growth rate and $\mathrm{CO}_{2}$ concentration on carbon isotopic fractionation by the marine diatom Phaeodactylum tricornutum, Limnol. Oceanogr., 42, https://doi.org/10.4319/lo.1997.42.7.1552, 1997a.

Laws, E. A., Bidigare, R. R., and Popp, B. N.: Effect of growth rate and $\mathrm{CO}_{2}$ concentration on carbon isotopic fractionation by the marine diatom Phaeodactylum tricornutum, Limnol. Oceanogr., 42, 1552-1560, 1997b. 
McClelland, J. W., Holmes, R. M., Peterson, B. J., Raymond, P. A., Striegl, R., Zhulidov, A. V., Zimov, S., Zimov, N., Tank, S. E., and Spencer, R. G.: Particulate organic carbon and nitrogen export from major Arctic rivers, Global Biogeochem. Cy., 30, 629-643, 2016.

Nieuwenhuize, J., Maas, Y. E., and Middelburg, J. J.: Rapid analysis of organic carbon and nitrogen in particulate materials, Mar. Chem., 45, 217-224, 1994.

Pagani, M., Arthur, M. A., and Freeman, K. H.: Miocene evolution of atmospheric carbon dioxide, Paleoceanography, 14, 273-292, 1999.

Pipko, I. I., Pugach, S. P., and Semiletov, I. P.: The autumn distribution of the $\mathrm{CO}_{2}$ partial pressure in bottom waters of the East Siberian Sea, Dokl. Earth Sci., 425, 345-349, 2009.

Popp, B. N., Laws, E. A., Bidigare, R. R., Dore, J. E., Hanson, K. L., and Wakeham, S. G.: Effect of phytoplankton cell geometry on carbon isotopic fractionation, Geochim. Cosmochim. Ac., 62, 69-77, 1998.

Popp, B. N., Trull, T., Kenig, F., Wakeham, S. G., Rust, T. M., Tilbrook, B., Griffiths, B., Wright, S. W., Marchant, H. J., and Bidigare, R. R.: Controls on the carbon isotopic composition of Southern Ocean phytoplankton, Global Biogeochem. Cy., 13, 827-843, 1999.

Purina, I., Balode, M., Béchemin, C., Põder, T., Vérité, C., and Maestrini, S.: Influence of dissolved organic matter from terrestrial origin on the changes of dinoflagellate species composition in the Gulf of Riga, Baltic Sea, Hydrobiologia, 514, 127-137, 2004.

Rau, G. H.: Variations in sedimentary organic $\delta^{13} \mathrm{C}$ as a proxy for past changes in ocean and atmospheric $\mathrm{CO}_{2}$ concentrations, in: Carbon Cycling in the Glacial Ocean: Constraints on the Ocean's Role in Global Change, Springer, Berlin, 1994.

Rau, G. H., Riebesell, U., and Wolf-Gladrow, D.: A model of photosynthetic ${ }^{13} \mathrm{C}$ fractionation by marine phytoplankton based on diffusive molecular $\mathrm{CO}_{2}$ uptake, Mar. Ecol.-Prog. Ser., 133, 275$285,1996$.

Salvadó, J. A., Tesi, T., Sundbom, M., Karlsson, E., Kruså, M., Semiletov, I. P., Panova, E., and Gustafsson, Ö.: Contrasting composition of terrigenous organic matter in the dissolved, particulate and sedimentary organic carbon pools on the outer East Siberian Arctic Shelf, Biogeosciences, 13, 6121-6138, https://doi.org/10.5194/bg-13-6121-2016, 2016.

Sánchez-García, L., Alling, V., Pugach, S., Vonk, J., van Dongen, B., Humborg, C., Dudarev, O., Semiletov, I., and Gustafsson, Ö.: Inventories and behavior of particulate organic carbon in the Laptev and East Siberian seas, Global Biogeochem. Cy., 25, https://doi.org/10.1029/2010GB003862, 2011.

Semiletov, I. P., Dudarev, O., Luchin, V., Charkin, A., Shin, K. H., and Tanaka, N.: The East Siberian Sea as a transition zone between Pacific-derived waters and Arctic shelf waters, Geophys. Res. Lett., 32, https://doi.org/10.1029/2005GL022490, 2005.

Semiletov, I. P., Shakhova, N. E., Pipko, I. I., Pugach, S. P., Charkin, A. N., Dudarev, O. V., Kosmach, D. A., and Nishino, S.: Spacetime dynamics of carbon and environmental parameters related to carbon dioxide emissions in the Buor-Khaya Bay and adjacent part of the Laptev Sea, Biogeosciences, 10, 5977-5996, https://doi.org/10.5194/bg-10-5977-2013, 2013.
Semiletov, I. P., Pipko, I., Gustafsson, O., Anderson, L. G., Sergienko, V., Pugach, S., Dudarev, O., Charkin, A., Gukov, A., Broder, L., Andersson, A., Spivak, E., and Shakhova, N.: Acidification of East Siberian Arctic Shelf waters through addition of freshwater and terrestrial carbon, Nat. Geosci., 9, 361-365, 2016.

Sobek, A. and Gustafsson, Ö.: Latitudinal fractionation of polychlorinated biphenyls in surface seawater along a $62^{\circ} \mathrm{N}-89^{\circ} \mathrm{N}$ transect from the southern Norwegian Sea to the North Pole area, Environ. Sci. Technol., 38, 2746-2751, 2004.

Spreen, G., Kaleschke, L., and Heygster, G.: Sea ice remote sensing using AMSR-E 89-GHz channels, J. Geophys. Res.-Oceans, 113, https://doi.org/10.1029/2005JC003384, 2008.

Tesi, T., Puig, P., Palanques, A., and Goñi, M.: Lateral advection of organic matter in cascading-dominated submarine canyons, Prog. Oceanogr., 84, 185-203, 2010.

Tesi, T., Semiletov, I., Hugelius, G., Dudarev, O., Kuhry, P., and Gustafsson, Ö.: Composition and fate of terrigenous organic matter along the Arctic land-ocean continuum in East Siberia: Insights from biomarkers and carbon isotopes, Geochim. Cosmochim. Ac., 133, 235-256, 2014.

Tesi, T., Muschitiello, F., Smittenberg, R. H., Jakobsson, M., Vonk, J. E., Hill, P., Andersson, A., Kirchner, N., Noormets, R., Dudarev, O., Semiletov, I., and Gustafsson, Ö.: Massive remobilization of permafrost carbon during post-glacial warming, Nat. Commun., 7, 13653, https://doi.org/10.1038/ncomms13653, 2016.

Torres-Valdés, S., Tsubouchi, T., Bacon, S., Naveira-Garabato, A. C., Sanders, R., McLaughlin, F. A., Petrie, B., Kattner, G., Azetsu-Scott, K., and Whitledge, T. E.: Export of nutrients from the Arctic Ocean, J. Geophys. Res.-Oceans, 118, 1625-1644, 2013.

Vonk, J., Sánchez-García, L., Van Dongen, B., Alling, V., Kosmach, D., Charkin, A., Semiletov, I. P., Dudarev, O. V., Shakhova, N., and Roos, P.: Activation of old carbon by erosion of coastal and subsea permafrost in Arctic Siberia, Nature, 489, 137-140, 2012.

Vonk, J. E., Semiletov, I. P., Dudarev, O. V., Eglinton, T. I., Andersson, A., Shakhova, N., Charkin, A., Heim, B., and Gustafsson, Ö.: Preferential burial of permafrost-derived organic carbon in Siberian-Arctic shelf waters, J. Geophys. Res.-Oceans, 119, 8410-8421, 2014.

Warnock, J. P. and Scherer, R. P.: A revised method for determining the absolute abundance of diatoms, J. Paleolimnol., 53, 157-163, 2015.

Wegner, C., Hölemann, J. A., Dmitrenko, I., Kirillov, S., Tuschling, K., Abramova, E., and Kassens, H.: Suspended particulate matter on the Laptev Sea shelf (Siberian Arctic) during ice-free conditions, Estuar. Coast. Shelf S., 57, 550-564, 2003.

Wikner, J. and Andersson, A.: Increased freshwater discharge shifts the trophic balance in the coastal zone of the northern Baltic Sea, Glob. Change Biol., 18, 2509-2519, 2012.

Wolf-Gladrow, D. A., Riebesell, U., Burkhardt, S., and Bijma, J.: Direct effects of $\mathrm{CO}_{2}$ concentration on growth and isotopic composition of marine plankton, Tellus B, 51, 461-476, 1999. 